Publisher policy allows this work to be made available in this repository. Published in Environmental Monitoring and Assessment, April 2018, 190:251. The final publication is available at Springer via https://doi.org/10.1007/s10661-018-6629-z

\title{
Demonstrating PM2.5 and road-side dust pollution by heavy metals along Thika superhighway in Kenya; sub-
} Saharan Africa

\section{E.G. Maina ${ }^{1 *}$, A. N. Gachanja ${ }^{1}$, M. J. Gatari ${ }^{2}$, and H. Price ${ }^{3}$}

${ }^{1}$ Department of Chemistry, Jomo Kenyatta University of Agriculture and Technology, P.O. Box 62000 - 00200, Nairobi, Kenya, agachanjah@yahoo.com

${ }^{2}$ Institute of Nuclear Science and Technology, College of Architecture and Engineering, University of Nairobi, P.O. Box 30197, G.P.O., Nairobi, Kenya, mgatari@uonbi.ac.ke

${ }^{3}$ School of Natural Sciences, University of Stirling, Stirling, United Kingdom, heather.price@ stir.ac.uk

1* Department of Chemistry, Jomo Kenyatta University of Agriculture and Technology, P.O. Box 62000 - 00200, Nairobi, Kenya, corresponding author (email: gachuie2@gmail.com)

\section{Abstract}

This study assessed the level of heavy metal in roadside dust and $\mathrm{PM}_{2.5}$ mass concentrations along Thika superhighway in Kenya. Thika superhighway is one of the busiest roads in Kenya, linking Thika town with Nairobi. Triplicate road dust samples collected from twelve locations were analysed for lead ( $\mathrm{Pb}$ ), chromium (Cr), cadmium (Cd), nickel (Ni), zinc $(\mathrm{Zn})$ and copper $(\mathrm{Cu})$ using Atomic Absorption Spectrophotometry (AAS). $\mathrm{PM}_{2.5}$ samples were collected on preweighed Teflon filters using a BGI personal sampler and the filters were then reweighed. The ranges of metal concentrations were 39 - $101 \mu \mathrm{g} / \mathrm{g}$ for Cu; 95 - $262 \mu \mathrm{g} / \mathrm{g}$ for Zn; 9 - $28 \mu \mathrm{g} / \mathrm{g}$ for Cd; 14 - $24 \mu \mathrm{g} / \mathrm{g}$ for Ni; 13 - $30 \mu \mathrm{g} / \mathrm{g}$ for $\mathrm{Cr}$ and $20-80 \mu \mathrm{g} / \mathrm{g}$ for $\mathrm{Pb}$. The concentrations of heavy metals were generally highly correlated, indicating a common anthropogenic source of the pollutants. The results showed that the majority of the measured heavy metals were above the background concentration, and in particular $\mathrm{Cd}, \mathrm{Pb}$ and $\mathrm{Zn}$ levels indicated moderate to high contamination. Though not directly comparable due to different sampling timeframes ( 8 hours in this study and 24 hours for guideline values), $\mathrm{PM}_{2.5}$ for all sites exceed the daily $\mathrm{WHO} \mathrm{PM}_{2.5}$ guidelines of $25 \mu \mathrm{g} / \mathrm{m}^{3}$. This poses a health risk to people using and working close to Thika superhighway, for example, local residents, traffic police, street vendors and people operating small businesses. $\mathrm{PM}_{2.5}$ levels were higher for sites closer to Nairobi which could be attributed to increased vehicular traffic towards Nairobi from Thika. This study provides some evidence of the air pollution problem arising from vehicular traffic in developing countries and gives an indication of the potential health impacts. It also highlights the need for source apportionment studies to determine contributions of anthropogenic emissions to air pollution, as well as long-term sampling studies that can be used to fully understand spatiotemporal patterns in air pollution within developing regions.

32 Keywords: $\mathrm{PM}_{2.5}$; Heavy metals; Roadside dust; Air pollution; Health; Vehicular emission; Atomic absorption spectrophotometer; Geoaccumulation; Contamination factor; Africa 


\section{Introduction} Air pollution is a major environmental health problem, causing millions of deaths every year around the World (WHO, 2014; Cohen et al., 2017). Although air quality has significantly improved in some cities, particularly in high-income countries, many low- and middle-income countries (LMICs) still suffer from very poor air quality which increases the burden of non-communicable diseases (Robinson and Hammitt 2009; Cohen et al., 2017). Air pollution has been linked to negative health impacts including cardiovascular diseases, stroke, lung cancer as well as chronic obstructive pulmonary disease (USEPA, 2015; WHO, 2016). Common sources of air pollution (heavy metals and particulate matter (PM)) in LMICs include vehicular emissions, industrial plants, power generation plants, oil burning, waste incineration, biomass burning, electric power generators, tire friction, motor oils spills, construction and demolition activities as well as re-suspension of surrounding contaminated soils and dust (Al-Khashman, 2004; van Vliet and Kinney, 2007; Amato et al 2009). A significant increase in vehicle ownership implies that vehicle emissions (both exhaust and non-exhaust emissions) have grown significantly over time, as it is estimated that 30,000 vehicles are added yearly in Kenyan roads (UNEP, 2006). There were approximately 1.5 million vehicles and 110,000 motorcycles registered in 2009 by the Kenya revenue authority. It can be estimated that there were about 3 to 3.5 million vehicles in Kenya in the years 2016 and 2017. This number is estimated to grow to 5 million in the year 2030. This increase in vehicle and motorcycle population results in more air pollution even if we consider clean vehicles produced with better technology to reduce emissions. In addition, a huge percentage of the vehicles in Kenya are used and may be 8 years old or above (Kenya Bureau of Standards, 2014). This increases the burden of pollution when compared to new vehicles (Kenduiwo., 2014). Together, these sources contribute to road dust heavy metal content and $\mathrm{PM}_{2.5}$ (particulate matter $\leq 2.5 \mu$ min diameter) air pollution.

Road dust comprises of particles of various sizes; some fine particulate matter $\left(\mathrm{PM}_{2.5} ;<2.5 \mu\right.$ m diameter $)$, respirable coarse particulates $(<10 \mu \mathrm{m}$ diameter) and non-respirable coarse particulates $(>10 \mu \mathrm{m}$ diameter $)$ derived from both anthropogenic (mobile and stationary) and natural sources. Previous roadside dust studies have highlighted enrichment of road dust with heavy metals like cadmium, lead and nickel due to traffic sources (Awadh, 2013). These heavy metals have been linked to adverse health effects including respiratory system disorders, nervous system interruptions, endocrine system malfunction, immune system suppression and the risk of cancer in later life (Atiemo et al., 2011). Road dust is important in health due to its composition. It may become airborne through suspension (or resuspension) by wind or vehicle movements (Amato et al 2009).

While the number of studies focused on air pollution and its impacts in Africa has increased over the last decade, (Victoria et al 2014: Gaita et al., 2014: Kinney et al 2011: van Vliet and Kinney 2007: Boman., 2013: Shinggu., 2010), there is still deficit in knowledge in African cities compared to other locations worldwide (Kinney et al., 2011; UNEP, 2016). This deficit is particularly acute given the high urbanisation and population growth rates observed in African countries (Ngo et al., 2015: Fengler., 2010). These urbanisation rates, combined with unregulated traffic activities, poorly maintained vehicles and limited air pollution control policies and or implementation, mean that air quality in sub-Saharan Africa (SSA) has deteriorated over time (Zachariadis et al., 2001; Ngo et al 2015). Even though previous studies have addressed regional aerosols in SSA (e.g. Gaita et al., 2014), there is little work that has focused in monitoring urban roadside particulate matter concentrations and in road dust chemistry, particularly in East African 
71 countries. Pollution concentrations near roadways are important in SSA cities because roadways are hubs of transport,

72 commerce, and other pedestrian activities, meaning that in these spaces high pollutant concentrations coincide with

73 high population exposure potential. Air pollutants tend to put a lot of pressure on the already weak medical system.

74 Some professions, e.g. street vendors, 'boda boda' riders and traffic police, as well as residents in houses close to

75 highways, who spend their days along roads and on congested roadsides are particularly predisposed to air pollutant

76 exposures (UNEP, 2006). In addition, Kinney et al. (2011) found that $49 \%$ of daily trips in Nairobi were either on foot

77 or on bicycle placing members of the public at risk of high exposure and from respiratory diseases.

78 Many studies agree that the construction of highways has positive effects on population growth, by attracting 79 immigrants, bringing an array of employment opportunities as well as housing developments (Boarnet and 80 Chalermpong, 2001; Chi et al., 2006). The expansion of Thika superhighway is no different, it has led to the radical 81 development of homes and businesses along the highway which has resulted in population growth along the 82 superhighway. In addition, the increasing number of vehicles and motorcycles in the country is a growing concern 83 due to their significant air pollutants input especially $\mathrm{CO}_{x}$ and particulate matter. (Kenduiwo, 2014; CAIP, 2000;).

84 In an attempt to address the effects of urbanisation, growth and development to the human population, this study aimed

85 to generate new understanding of the influence of vehicle emissions to road dust chemistry and $\mathrm{PM}_{2.5}$ concentrations in urban Kenya.

87 88

\section{Methodology}

\section{Study area}

The area of study was along Thika superhighway and in Thika town. Thika superhighway is a modern highway approximately $45 \mathrm{~km}$ long in length. It is part of an international trunk road connecting Nairobi city with Ethiopia to the north (Figure 1). It starts at Muthaiga roundabout, proceeds to Kasarani, Githurai Interchange, Kenyatta University, Ruiru Town, Juja Town and ends at the bridge near Blue Post Hotel in Thika. The land along the study site is experiencing radical developmental change as new building are constructed every day. Land close to Thika town is currently utilised for real-estate a shift from small scale agriculture. Whereas close to Nairobi, the land has been utilised for construction of commercial and domestic buildings. There are a few manufacturing industries in Ruiru and in Allsops, with most of them being in Ruiru. The population of towns/constituencies along Thika superhighway according to the 2009 census are estimated to be: 136,917 people for Thika, 40,446 for Juja, 238,858 for Ruiru, 191,690 for Roysambu, 194,120 for Ruaraka and 166,044 for Starehe. The human population of all these places increases every year (NCIDP, 2014; Gicaci, 2015; Kenya National Bureau of Statistics, 2013). 


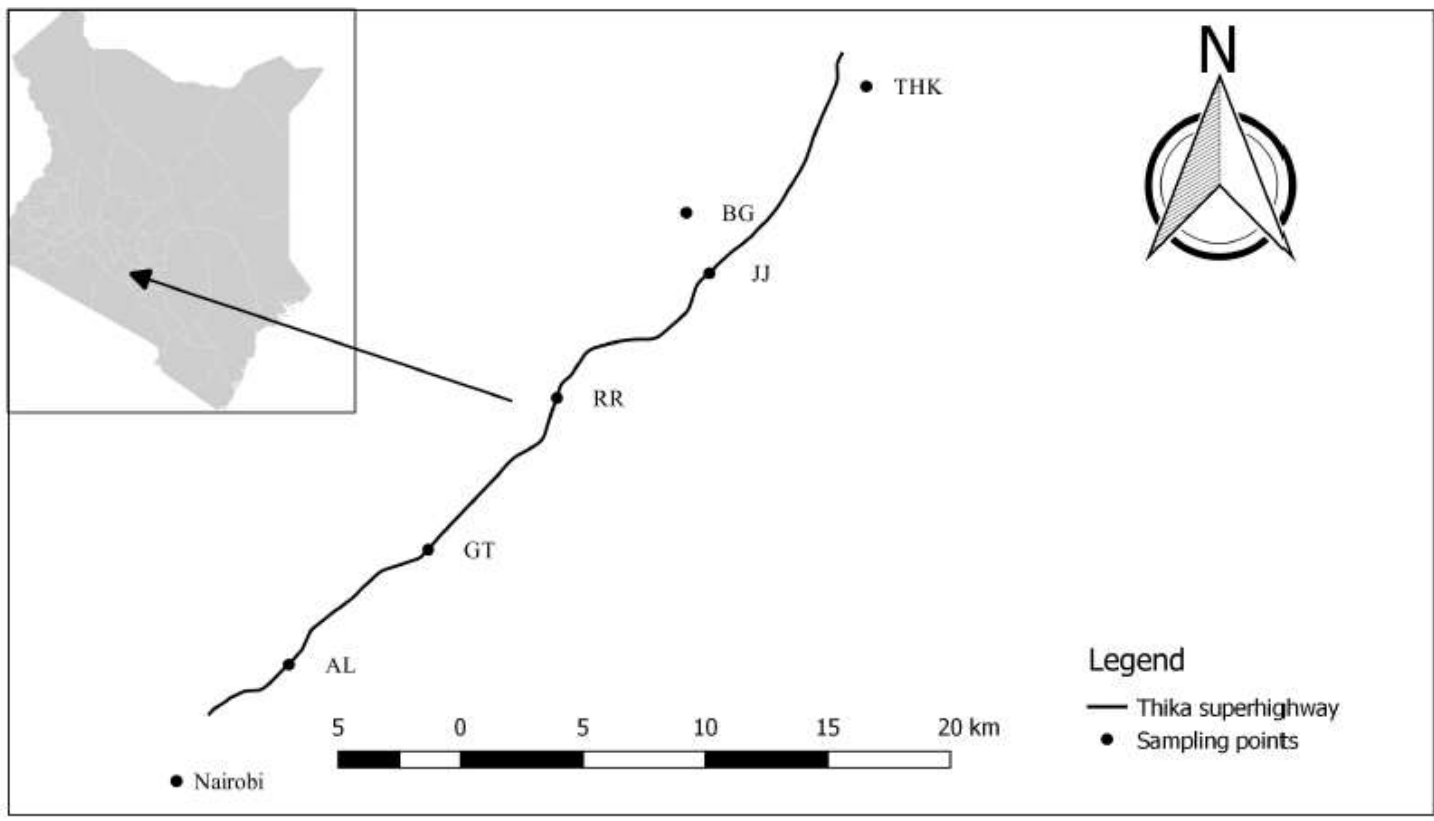

Figure 1:

Map showing the locations of sampling sites along Thika superhighway. Further details about sampling sites are given in Table 1. (Thika superhighway. [Computer generated map]. Digitised from Google Earth using QGIS. [GIS software].Version2.18.17.2018).

The sampling points selected for this study were Allsops (AL), Githurai (GT), Ruiru bus terminus (RR), Jomo Kenyatta University bus terminus (JJ), Commercial Street Thika (THK) and Jomo Kenyatta University as a rural background (BG) site (Table 1). Thika superhighway is one of the busiest roads in Kenya, which was expanded in 2012 into a superhighway. In a study done in 2015, it was reported that the traffic volume in this highway was 1998 vehicles/hour/lane during peak hours and 1300 vehicles/hour/lane in off-peak hours (Kabui, 2015).

111 Table 1: Sample locations and codes, where W designates western side of the highway while E is eastern side

\begin{tabular}{|c|c|c|c|c|}
\hline $\begin{array}{l}\text { Sample } \\
\text { location } \\
\text { code }\end{array}$ & Area & Longitude & Latitude & Elevation $(\mathrm{m})$ \\
\hline BG & Jomo Kenyatta University & $37^{\circ} 0^{\prime} 34.14 " \mathrm{E}$ & $1^{\circ} 4^{\prime} 58.57^{\prime \prime S}$ & 1531 \\
\hline THK W & Thika & $37^{\circ} 4^{\prime} 31.14^{\prime \prime} \mathrm{E}$ & $1^{\circ} 2^{\prime} 12.00^{\prime \prime} \mathrm{S}$ & 1507 \\
\hline THK E & Thika & $37^{\circ} 4^{\prime} 31.87^{\prime \prime E}$ & $1^{\circ} 2^{\prime} 11.83^{\prime \prime S}$ & 1507 \\
\hline JJ W & Jomo Kenyatta bus terminus & $37^{\circ} 1{ }^{\prime} 3.17^{\prime \prime} \mathrm{E}$ & $1^{\circ} 6^{\prime} 16.88^{\prime \prime S}$ & 1518 \\
\hline JJ E & Jomo Kenyatta bus terminus & $37^{\circ} 1^{\prime} 4.48^{\prime \prime} \mathrm{E}$ & $1^{\circ} 6^{\prime} 18.31^{\prime \prime S}$ & 1518 \\
\hline RR W & Ruiru & $36^{\circ} 57^{\prime} 40.77 " \mathrm{E}$ & $1^{\circ} 9^{\prime} 5.95 " \mathrm{~S}$ & 1525 \\
\hline RR E & Ruiru & $36^{\circ} 57^{\prime} 43.05^{\prime \prime} \mathrm{E}$ & $1^{\circ} 9^{\prime} 3.08^{\prime \prime S}$ & 1525 \\
\hline GT W & Githurai & $36^{\circ} 54^{\prime} 52.07 " \mathrm{E}$ & $1^{\circ} 12^{\prime} 22.62^{\prime \prime S}$ & 1540 \\
\hline GT E & Githurai & $36^{\circ} 54^{\prime} 52.92 " \mathrm{E}$ & $1^{\circ} 12^{\prime} 23.45^{\prime \prime S}$ & 1540 \\
\hline $\mathrm{AL} \mathrm{W}$ & Allsops & $36^{\circ} 51^{\prime} 47.23 " \mathrm{E}$ & $1^{\circ} 14^{\prime} 54.11^{\prime \prime S}$ & 1630 \\
\hline
\end{tabular}




\begin{tabular}{|l|l|l|l|l|}
\hline AL E & Allsops & $36^{\circ} 51^{\prime} 48.94 " \mathrm{E}$ & $1^{\circ} 14^{\prime} 55.27 " \mathrm{~S}$ & 1630 \\
\hline
\end{tabular}

112 At each site (Figure 1, Table 1), road dust samples were collected and analysed to determine the level of heavy

113 metals contamination, relative to the background site. Furthermore, at each site, $\mathrm{PM}_{2.5}$ mass concentrations were

114 measured to determine the contribution of road traffic to atmospheric $\mathrm{PM}_{2.5}$.

\section{Road dust chemistry}

\section{Sampling process}

118 The collection of road dust samples was comparable to previous work undertaken elsewhere (e.g. in Europe; Amato

119 et al., 2009 and Africa; Abah et al., 2014). Half a meter from the pavement edge, two sub-samples from each

120 sampling site were collected within a $1 \mathrm{~m}^{2}$ area. Dust was obtained by sweeping the pavement with a plastic brush

121 and a plastic dustpan, put in a clean polyethylene bag which was sealed, labelled and transported to the laboratory

122 for analysis (Raj and Ram, 2013).

123 Sample preparation, digestion and analysis

124 To determine the level of heavy metals $(\mathrm{Pb}, \mathrm{Cr}, \mathrm{Fe}, \mathrm{Cu}, \mathrm{Ni}$ and $\mathrm{Zn})$, the collected road dust samples were air dried at 125 room temperature for 5 days to a constant weight and then sieved through a $125 \mu$ m stainless steel mesh wire (Abah 126 et al., 2014). $1 \mathrm{~g}$ of the sample was weighed to the nearest $0.001 \mathrm{~g}$ and transferred to a round-bottomed flask. $10 \mathrm{ml}$ of $12750 \%(\mathrm{v} / \mathrm{v}) \mathrm{HNO}_{3}$ was added to the sample and the sample was mixed. The flask containing the mixture was covered with a watch glass. The sample was heated to $95^{\circ} \mathrm{C}$ and then refluxed for 10 to 15 minutes without boiling. The sample was cooled and $5 \mathrm{ml}$ of concentrated $\mathrm{HNO}_{3}$ was added. The cover was replaced followed by refluxing for 30 minutes. In case brown fumes were generated due to oxidation of the sample, this step was repeated continuously until there was no further formation of the brown fumes. The resulting solution was heated at $95^{\circ} \mathrm{C}$ without boiling for two hours. The sample was cooled and then $2 \mathrm{ml}$ of water and $3 \mathrm{ml}$ of $30 \% \mathrm{H}_{2} \mathrm{O}_{2}$ was added to the solution. The vessel was covered using a watch glass and returned to the heat source for warming, to start the peroxide reaction. The sample was heated until the effervescence subsided after which the vessel was cooled. $1 \mathrm{ml}$ aliquots of $30 \% \mathrm{H}_{2} \mathrm{O}_{2}$ were added continuously with warming until the sample appearance remained unchanged. The sample was covered using an allihn condenser to recover the vapour. The heating of the acid-peroxide digestate was left to continue until the volume reduced to approximately $5 \mathrm{ml} .10 \mathrm{ml}$ concentrated $\mathrm{HCl}$ was added to the sample digestate. A vapour recovery device was used to cover the sample. The sample was placed in the heating source and refluxed at $95^{\circ} \mathrm{C}$ for 15 minutes. The resulting digestate was filtered through Whatman filter paper No. 41 (USEPA, 1996) and the filtrate transferred into a $100 \mathrm{ml}$ volumetric flask and distilled water added to $100 \mathrm{ml}$ mark. The solutions were aspirated into the FAAS instrument, Shimadzu AA-6200 (experimental conditions are outlined in Table 2). The detection limits for the metals were found to be; $\mathrm{Zn} 0.01459 \mu \mathrm{g} / \mathrm{g}, \mathrm{Cu} 0.1836 \mu \mathrm{g} / \mathrm{g}, \mathrm{Cd} 0.02795 \mu \mathrm{g} / \mathrm{g}$, Ni $0.0854 \mu \mathrm{g} / \mathrm{g}, \mathrm{Cr} 0.0474 \mu \mathrm{g} / \mathrm{g}$ and Pb 0.2612 $\mu \mathrm{g} / \mathrm{g}$.

144 Table 2: Atomic absorption spectrophotometer conditions

\begin{tabular}{|l|l|l|l|l|}
\hline Element & Wavelength $(\mathrm{nm})$ & $\begin{array}{l}\text { Fuel gas flow rate } \\
(\mathrm{L} / \mathrm{min})\end{array}$ & $\begin{array}{l}\text { Lamp current } \\
(\mathrm{mA})\end{array}$ & $\begin{array}{l}\text { Slit width } \\
(\mathbf{n m})\end{array}$ \\
\hline
\end{tabular}




\begin{tabular}{|l|l|l|l|l|}
\hline Pb & 283.3 & 2.0 & 10 & 0.7 \\
\hline $\mathrm{Cr}$ & 357.9 & 2.8 & 10 & 0.7 \\
\hline $\mathrm{Cu}$ & 324.8 & 1.8 & 6 & 0.7 \\
\hline $\mathrm{Cd}$ & 228.8 & 1.8 & 8 & 0.7 \\
\hline $\mathrm{Ni}$ & 232.0 & 1.6 & 12 & 0.2 \\
\hline $\mathrm{Zn}$ & 213.9 & 2.0 & 8 & 0.7 \\
\hline
\end{tabular}

145 Assessment of contamination

146 There are several indices that may be used to assess the level of contamination of heavy metals in road dust. For this

147 study, the Geo-accumulation index (I-geo) and the contamination factor (CF) were selected to evaluate the

148 contamination level of $\mathrm{Zn}, \mathrm{Cu}, \mathrm{Cd}, \mathrm{Ni}, \mathrm{Cr}$ and $\mathrm{Pb}$ in the roadside dust, based on their common usage in similar work

149 (e.g. Addo et al., 2012; Awadh, 2013). The index of Geo-accumulation (I-geo) assessed the level of contamination by

150 comparing the concentration of heavy metals obtained to background levels which are bottom sediments in this case.

151 The Geo-accumulation (I-geo) index was calculated using the following equation:

$$
\mathrm{I}_{\mathrm{geo}}=\log _{2}\left(\frac{\mathrm{Cn}}{1.5 \mathrm{Bn}}\right) \quad \text { eq. } 1
$$

In the I-geo index, $\mathrm{Cn}$ is the measured concentration of the heavy metal in the road dust sample and $\mathrm{Bn}$ is the geochemical background concentration of the heavy metal (Robertson et al 2003; Taylor, 1964). The constant 1.5 in equation 1 minimizes the effect of possible variations in the background values which may be attributed to lithologic variations in the sediments. The values of this index vary from sub-zero to more than 5. The highest grade (6) reflects a 100-fold enrichment and (0) reflects the background concentration. 0-1 indicate unpolluted to moderate pollution, 1-2 indicate moderate pollution, 2-3 indicate moderate to strong pollution, 3-4 indicate strong pollution, 4-5 indicate strong to extreme pollution while values $>5$ indicate extreme pollution.

For comparison with the I-geo index, the contamination factor (CF) was also calculated for all samples. The CF was calculated as:

$\mathrm{CF}$ is the contamination factor, $\mathrm{Cm}$ sample is the concentration of the metal in the sample and $\mathrm{Cm}_{\text {background }}$ is the metal concentration in the background sample. The $\mathrm{CF}$ reflects the metal enrichment in the sediment; a $\mathrm{CF}<1$ indicates low contamination, $1 \leq \mathrm{CF}<3$ indicates moderate contamination, $3 \leq \mathrm{CF} \leq 6$ indicates high contamination and $\mathrm{CF}>6$ indicates very high contamination.

PM2.5 sampling procedure

Sampling of $\mathrm{PM}_{2.5}$ was carried out at the five sampling sites along Thika superhighway during the months of March and April 2017 (dry season). The background and roadway monitoring of $\mathrm{PM}_{2.5}$ were undertaken using a portable air sampling system, BGI (Kinney et al., 2011). Samples were collected on pre-weighed teflon filters for $8 \mathrm{~h}$ per sample at a flow rate of $4 \mathrm{~L}$ per minute, with air being drawn by a calibrated BGI personal sampling pump. At each site, 
173 sampling was conducted between 06:30 hrs and 14:30 hrs local time, for five non-consecutive weekdays. During the 174 sampling period, humidity ranged from $57 \%$ to $69 \%$, temperature $21^{\circ} \mathrm{C}$ to $23^{\circ} \mathrm{C}$ and wind $8 \mathrm{Km} / \mathrm{h}$ to $14 \mathrm{Km} / \mathrm{h}$.

\section{Results and discussion}

176

177 Road dust chemistry

178

179 The heavy metals $(\mathrm{Zn}, \mathrm{Cu}, \mathrm{Cd}, \mathrm{Cr}, \mathrm{Ni}$ and $\mathrm{Pb})$ concentrations in road dust are listed in Table 3 and the spatial 180 distribution of these metals in road dust are illustrated in Figure 2. 
181 Table 3: Mean heavy metal concentrations in the roadside dust $(\mathrm{n}=3)$ with standard deviations given in brackets.

\begin{tabular}{|c|c|c|c|c|c|c|c|c|c|c|c|c|c|}
\hline \multicolumn{2}{|c|}{ Sampling Points } & Cu N-T & Cu T-N & Zn N-T & Zn T-N & Cd N-T & Cd T-N & Ni N-T & Ni T-N & Cr N-T & Cr T-N & Pb N-T & Pb T-N \\
\hline \multirow[t]{3}{*}{$\mathbf{A L}$} & Mean & 101.40 & 85.11 & 262.18 & 254.89 & 25.52 & 27.68 & 14.34 & 14.34 & 22.73 & 17.95 & 49.16 & 51.59 \\
\hline & $\mathrm{N}$ & 3 & 3 & 3 & 3 & 3 & 3 & 3 & 3 & 3 & 3 & 3 & 3 \\
\hline & $\begin{array}{l}\text { Std. } \\
\text { Deviation }\end{array}$ & 1.80 & 4.12 & 2.23 & 2.26 & 0.21 & 0.44 & 0.84 & 2.33 & 1.09 & 0.86 & 3.03 & 3.03 \\
\hline \multirow[t]{3}{*}{ BG } & Mean & 39.19 & 40.99 & 94.91 & 94.98 & 8.68 & 10.69 & 16.43 & 17.69 & 14.70 & 12.98 & 20.49 & 20.49 \\
\hline & $\mathrm{N}$ & 3 & 3 & 3 & 3 & 3 & 3 & 3 & 3 & 3 & 3 & 3 & 3 \\
\hline & $\begin{array}{l}\text { Std. } \\
\text { Deviation }\end{array}$ & 2.57 & 2.35 & 1.28 & 0.85 & 0.48 & 0.39 & 1.11 & 1.83 & 1.16 & 0.72 & 1.46 & 2.53 \\
\hline \multirow[t]{3}{*}{ JJ } & Mean & 57.29 & 54.12 & 154.24 & 203.88 & 15.38 & 18.78 & 16.85 & 23.54 & 17.09 & 17.28 & 46.24 & 56.93 \\
\hline & $\mathrm{N}$ & 3 & 3 & 3 & 3 & 3 & 3 & 3 & 3 & 3 & 3 & 3 & 3 \\
\hline & $\begin{array}{l}\text { Std. } \\
\text { Deviation }\end{array}$ & 0.68 & 0.79 & 1.18 & 3.11 & 0.37 & 0.43 & 1.11 & 2.33 & 0.57 & 1.36 & 3.04 & 2.92 \\
\hline \multirow[t]{3}{*}{ RR } & Mean & 72.67 & 82.62 & 168.41 & 238.22 & 20.03 & 20.59 & 19.36 & 17.96 & 13.27 & 17.95 & 41.87 & 43.33 \\
\hline & $\mathrm{N}$ & 3 & 3 & 3 & 3 & 3 & 3 & 3 & 3 & 3 & 3 & 3 & 3 \\
\hline & $\begin{array}{l}\text { Std. } \\
\text { Deviation }\end{array}$ & 3.21 & 2.18 & 2.18 & 0.50 & 0.78 & 1.16 & 0.42 & 1.34 & 0.44 & 0.86 & 4.45 & 1.68 \\
\hline \multirow[t]{3}{*}{ GT } & Mean & 85.57 & 98.69 & 227.22 & 198.28 & 22.39 & 23.72 & 19.22 & 16.57 & 17.19 & 17.28 & 49.16 & 39.93 \\
\hline & $\mathrm{N}$ & 3 & 3 & 3 & 3 & 3 & 3 & 3 & 3 & 3 & 3 & 3 & 3 \\
\hline & $\begin{array}{l}\text { Std. } \\
\text { Deviation }\end{array}$ & 3.73 & 2.45 & 1.18 & 0.74 & 0.55 & 1.15 & 2.79 & 1.74 & 0.33 & 0.92 & 2.23 & 2.23 \\
\hline \multirow[t]{3}{*}{ THK } & Mean & 74.70 & 75.16 & 197.69 & 241.15 & 11.93 & 15.70 & 20.89 & 21.03 & 22.92 & 29.13 & 80.26 & 72.48 \\
\hline & $\mathrm{N}$ & 3 & 3 & 3 & 3 & 3 & 3 & 3 & 3 & 3 & 3 & 3 & 3 \\
\hline & $\begin{array}{l}\text { Std. } \\
\text { Deviation }\end{array}$ & 1.04 & 1.42 & 2.52 & 0.37 & 0.24 & 0.37 & 1.69 & 2.17 & 2.60 & 0.86 & 1.46 & 0.84 \\
\hline
\end{tabular}


The concentration of most of the metals (e.g. $\mathrm{Zn}, \mathrm{Cu}$ and $\mathrm{Pb}$ ) are higher in sites closer to the urban areas of Nairobi city and Thika town (Figure 2), which is attributable to the greater volume of vehicular traffic near the highlypopulated conurbations. All these metals were suspected to originate from vehicular emissions since there was the absence of any close industries near the sampling sites (Victoria et al., 2014; Nabulo et al., 2006). In the case of Allsops (AL) sampling site, it had the highest $\mathrm{Zn}$ concentration with an average of $262.2 \mu \mathrm{g} / \mathrm{g}$ which is comparable to Dhaka and Amman studies (Ahmed et al., 2006; Al-Khashman 2004), whereas Juja (JJ) had lower concentration with an average of $154.2 \mu \mathrm{g} / \mathrm{g}$. The background site had lowest $\mathrm{Zn}$ concentrations $(94.9 \mu \mathrm{g} / \mathrm{g})$ when compared to the other roadside sites. AL site had the highest $\mathrm{Cu}$ concentration, with an average of $101.4 \mu \mathrm{g} / \mathrm{g}$, and JJ was lower with an average of $54.1 \mu \mathrm{g} / \mathrm{g}$, compared to $39.2 \mu \mathrm{g} / \mathrm{g}$ at the background site. These results are above those obtained in Ketusouth, Ghana $(60.53 \mu \mathrm{g} / \mathrm{g})$ showing that the sites in this study are highly polluted (Addo et al., 2012). The site with the highest concentration of $\mathrm{Cd}$ was $\mathrm{AL}$ with a concentration of $277.0 \mu \mathrm{g} / \mathrm{g}$, while the lowest concentration of 11.9 $\mu \mathrm{g} / \mathrm{g}$ was measured at Commercial Street Thika (THK). For comparison, the background site had a concentration of $8.7 \mu \mathrm{g} / \mathrm{g}$. In the case of $\mathrm{Ni}, \mathrm{JJ}$ had the highest mean concentration of $23.5 \mu \mathrm{g} / \mathrm{g}$ while THK had the lowest concentration of $14.3 \mu \mathrm{g} / \mathrm{g}$. The background $\mathrm{Ni}$ concentration was slightly higher than THK at $16.4 \mu \mathrm{g} / \mathrm{g}$. In terms of $\mathrm{Cr}$ concentration, THK was highest with an average concentration of $29.1 \mu \mathrm{g} / \mathrm{g}$, this was close to the concentration obtained in Luanda, Angola reported as $26 \mu \mathrm{g} / \mathrm{g}$ (Ordonez et al., 2003). The lowest concentration was at Ruiru (RR) with an average of $13.3 \mu \mathrm{g} / \mathrm{g}$, which was slightly above the background site concentration $(13.0 \mu \mathrm{g} / \mathrm{g})$. The site with the highest $\mathrm{Pb}$ concentration was THK with an average of $72.5 \mu \mathrm{g} / \mathrm{g}$ and the lowest was RR (average of $39.9 \mu \mathrm{g} / \mathrm{g}$ ), while the background site had an average concentration of $20.5 \mu \mathrm{g} / \mathrm{g}$. This is comparable to Kampala, Uganda reported as $45.3 \mu \mathrm{g} / \mathrm{g}$ (Nabulo et al., 2006).

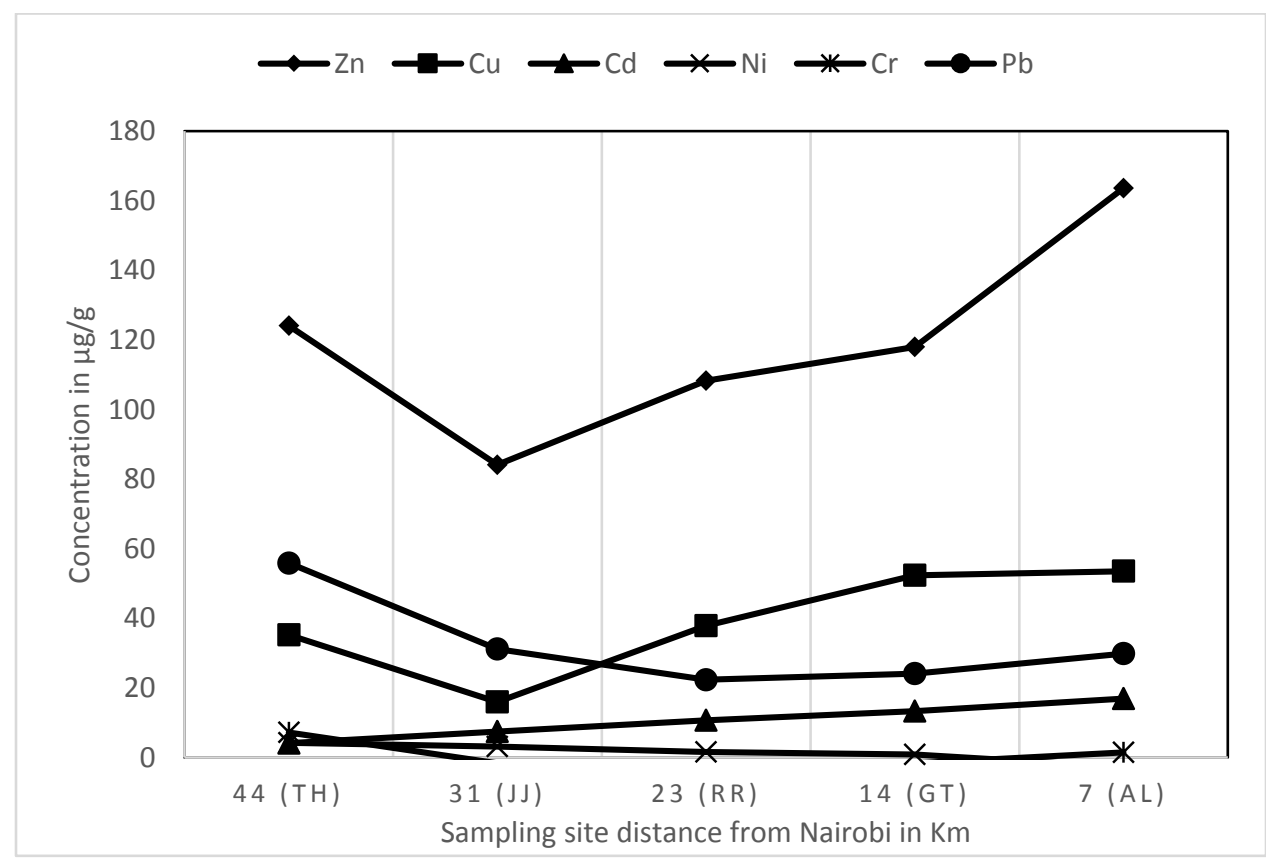

Figure 2: Concentration of heavy metals ( $\mathrm{Zn}, \mathrm{Cu}, \mathrm{Cd}, \mathrm{Ni}, \mathrm{Cr}$ and $\mathrm{Pb}$ ) along Thika superhighway in $\mu \mathrm{g} / \mathrm{g}$. The background concentration of each metal has been subtracted, implying that the concentration level is the enrichment of that metal at the site. 
207 The I-geo shows that most of the road sites are moderately polluted by $\mathrm{Zn}$ and $\mathrm{Pb}$, with I-geo scores ranging from 0

208 to 2, except for $\mathrm{Cd}$ which had all I-geo values greater than 5, indicating extreme pollution in the road dust. In the

209 case of $\mathrm{Ni}, \mathrm{Cr}$ and $\mathrm{Cu}$, nominal or negative values for most sites indicated that the sites were not enriched with those

210 metals when compared to the background site. The contamination factors ( $\mathrm{CFs}$ ) for $\mathrm{Zn}, \mathrm{Cu}, \mathrm{Cd}, \mathrm{Ni}, \mathrm{Cr}$ and $\mathrm{Pb}$ were

211 calculated for the study area (Table 4). In most of the sites, there was moderate contamination of all metals with CF

212 values ranging between 1 and $3 . \mathrm{Cd}$ and $\mathrm{Pb}$ had some $\mathrm{CF}$ values which were over 3, indicating the road dust samples

213 were more contaminated with these metals, for example, Al site had a CF of 3.1 for Cd, while THK site had CF

214 value of 3.9 for $\mathrm{Pb}$. The lowest contamination factor of all the metals was at JJ site whose $\mathrm{CF}$ was 0.6 for $\mathrm{Cr}$, which

215 indicated low contamination. The source of these pollutants could be attributed to exhaust and non-exhaust vehicular

216 emission since there are no industries close to Thika superhighway except at RR. No anomaly was observed in the

217 RR results that could be attributable to industrial emissions (Xia et al.,2011). 
Table 4. Enrichment factors for heavy metals in Thika superhighway road dust using the geo-accumulation index (I-geo) and Contamination Factor (CF) analysis

\begin{tabular}{|l|l|l|l|l|l|l|l|l|l|l|l|l|}
\hline $\begin{array}{l}\text { Sampling } \\
\text { site }\end{array}$ & Zn & & Cu & & Cd & & Ni & & Cr & & Pb & \\
\hline & I-geo & CF & I-geo & CF & I-geo & CF & I-geo & CF & I-geo & CF & I-geo & CF \\
\hline THK W & 0.9 & 2.1 & -0.1 & 1.9 & 5.7 & 1.4 & -2.4 & 1.3 & -2.7 & 1.6 & 2.1 & 3.9 \\
\hline THK E & 1.2 & 2.5 & -0.1 & 1.9 & 6.1 & 1.8 & -2.4 & 1.2 & -2.4 & 2.2 & 2.0 & 3.5 \\
\hline JJ W & 0.6 & 1.6 & -0.5 & 1.5 & 6.1 & 1.8 & -2.7 & 0.8 & -3.1 & 0.7 & 1.3 & 2.3 \\
\hline JJ E & 1.0 & 2.1 & -0.6 & 1.4 & 6.4 & 2.2 & -2.3 & 1.1 & -3.1 & 0.6 & 1.6 & 2.8 \\
\hline RR W & 0.7 & 1.8 & -0.2 & 1.9 & 6.5 & 2.3 & -2.5 & 1.1 & -3.5 & 0.8 & 1.2 & 2.0 \\
\hline RR E & 1.2 & 2.5 & 0.0 & 2.1 & 6.5 & 2.4 & -2.6 & 0.8 & -3.1 & 1.0 & 1.2 & 2.1 \\
\hline GT W & 1.1 & 2.4 & 0.1 & 2.2 & 6.6 & 2.6 & -2.5 & 1.0 & -3.1 & 1.3 & 1.4 & 2.4 \\
\hline GT E & 0.9 & 0.8 & 0.3 & 2.5 & 6.7 & 2.7 & -2.8 & 0.9 & -3.1 & 1.0 & 1.1 & 1.9 \\
\hline AL W & 1.3 & 2.8 & 0.3 & 2.6 & 6.8 & 2.9 & -3.0 & 0.7 & -2.7 & 1.3 & 1.4 & 2.4 \\
\hline AL E & 1.3 & 2.7 & 0.0 & 2.2 & 6.9 & 3.2 & -3.0 & 0.9 & -3.1 & 1.0 & 1.5 & 2.5 \\
\hline
\end{tabular}


220 Pearson's Correlation Coefficient (r) identified that there was a positive correlation between most of the measured

221 heavy metals in the road dust (Table 5), which indicated a common source of the metals (Victoria et al., 2014).

222 Elemental pairs $\mathrm{Cu} / \mathrm{Zn}(\mathrm{r}=0.986), \mathrm{Cu} / \mathrm{Cd}(\mathrm{r}=0.908)$, and $\mathrm{Zn} / \mathrm{Cd}(\mathrm{r}=0.830)$, had $\mathrm{r}$ values above 0.5 indicating strong

223 correlation with each other. On the other hand, pairs such as $\mathrm{Cu} / \mathrm{Cr}(\mathrm{r}=0.291), \mathrm{Cd} / \mathrm{Pb}(\mathrm{r}=0.107)$ and $\mathrm{Pb} / \mathrm{Ni}(\mathrm{r}=0.356)$

224 showed moderate relationships. Elemental pairs $\mathrm{Cu} / \mathrm{Ni}(\mathrm{r}=-0.054), \mathrm{Zn} / \mathrm{Ni}(\mathrm{r}=-0.061), \mathrm{Ni} / \mathrm{Cd}(\mathrm{r}=-0.258)$ and $\mathrm{Cd} / \mathrm{Cr}(\mathrm{r}=-$

225 0.111) indicated inverse relationship. The results showing positive correlation indicate that these metals originated

226 from a common anthropogenic source most probably vehicular emission (Abah et al 2014; Addo et al 2012). This was

227 expected as $\mathrm{Zn}, \mathrm{Cu}, \mathrm{Ni}, \mathrm{Cr}$ and $\mathrm{Cd}$ are commonly produced from brake wear and tyre wear (Shinggu et al., 2010).

228 Similarly, $\mathrm{Cu}$ and $\mathrm{Cr}$ have been reported to originate from exhaust emissions (Yu et al., 2003). 
Table 5. The correlation coefficient, $r$, between concentrations of heavy metal along Thika superhighway (Kenya).

\begin{tabular}{|l|l|l|l|l|l|l|l|l|l|l|l|l|}
\hline & Cu N-T & Cu T-N & ZnN-T & Zn T-N & Cd N-T & Cd T-N & Ni N-T & Ni T-N & Cr N-T & Cr T-N & Pb N-T & Pb T-N \\
\hline Cu N-T & 1 & & & & & & & & & & \\
\hline Cu T-N & $.884^{*}$ & 1 & & & & & & & & & \\
\hline Zn N-T & $.986^{* *}$ & $.854^{*}$ & 1 & & & & & & & & \\
\hline Zn T-N & .810 & .707 & .783 & 1 & & & & & & & & \\
\hline Cd N-T & $.872^{*}$ & .810 & $.833^{*}$ & .650 & 1 & & & & & & & \\
\hline Cd T-N & $.908^{*}$ & .793 & $.891^{*}$ & .717 & $.984^{* *}$ & 1 & & & & & \\
\hline Ni N-T & -.054 & .305 & -.061 & .190 & -.258 & -.274 & 1 & & & & \\
\hline Ni T-N & -.512 & -.456 & -.440 & -.015 & -.597 & -.507 & .416 & 1 & & & \\
\hline Cr N-T & .594 & .291 & .670 & .532 & .197 & .341 & -.089 & -.028 & 1 & & \\
\hline Cr T-N & .332 & .314 & .364 & .604 & -.111 & -.007 & .629 & .400 & .665 & 1 & & \\
\hline Pb N-T & .510 & .477 & .561 & .722 & .107 & .225 & .553 & .344 & .736 & $.959^{* *}$ & 1 \\
\hline Pb T-N & .438 & .306 & .487 & .782 & .116 & .256 & .356 & .500 & .698 & $.870^{*}$ & $.924^{* *}$ & 1 \\
\hline
\end{tabular}


$\mathrm{PM}_{2.5}$ concentrations generally increased towards Nairobi town (Figure 3), with the highest mean concentration being at JJ with $509 \mu \mathrm{g} / \mathrm{m}^{3}$. This was attributable to dust storms (Al-Khashman, 2004; Amato et al 2009; Lindén et $a l ., 2012$ ), which were experienced on one sampling day at $\mathrm{JJ}$ which skewed the site average (Figure 4), and therefore the mean $\mathrm{PM}_{2.5}$ concentration was recalculated for the four remaining sampling days giving $36.24 \mu \mathrm{g} / \mathrm{m}^{3}$ (Figure 3). Most of the study sites had high $\mathrm{PM}_{2.5}$ concentrations during Monday, Wednesday and on Friday (Figure 4), which could be attributed to the high human-related activities along the road/highway as people are coming back to the city from their rural home and as well going back to their rural homes on Mondays and Fridays respectively (Kinney et al., 2011). $\mathrm{PM}_{2.5}$ concentrations were higher than those observed in many European and American studies, but was similar to studies undertaken in other African countries; Accra, Ghana (Aboh et al., 2009), Ouagadougou, Burkina Faso (Boman et al., 2009) and Cairo, Egypt (Boman et al., 2013). All the sites in this study had lower $\mathrm{PM}_{2.5}$ concentrations when compared to a study completed in February 2006 between Nairobi and Ruiru, Kenya, which was conducted by van Vliet et al., 2007 who reported $\mathrm{PM}_{2.5}$ concentrations of $414 \mu \mathrm{g} / \mathrm{m}^{3}$. This difference may be due to the different sampling protocols and sampling periods employed in the two studies. However, the average $\mathrm{PM}_{2.5}$ concentration for Thika town measured in this study $\left(69 \mu \mathrm{g} / \mathrm{m}^{3}\right)$ was higher than observed Gaita et al.'s 2014 study in Nairobi who reported an average concentration of $21 \mu \mathrm{g} / \mathrm{m}^{3}$, but it was lower when compared to the results $\left(98.1 \mu \mathrm{g} / \mathrm{m}^{3}\right)$ reported by Kinney et al 2011 in a side walk within Nairobi central business district. Even though the results obtained cannot be compared with WHO daily guidelines since sampling was done for only 8hrs, all the roadside sampling sites had $\mathrm{PM}_{2.5}$ levels higher than daily WHO guideline of $25 \mu \mathrm{g} / \mathrm{m}^{3}$.

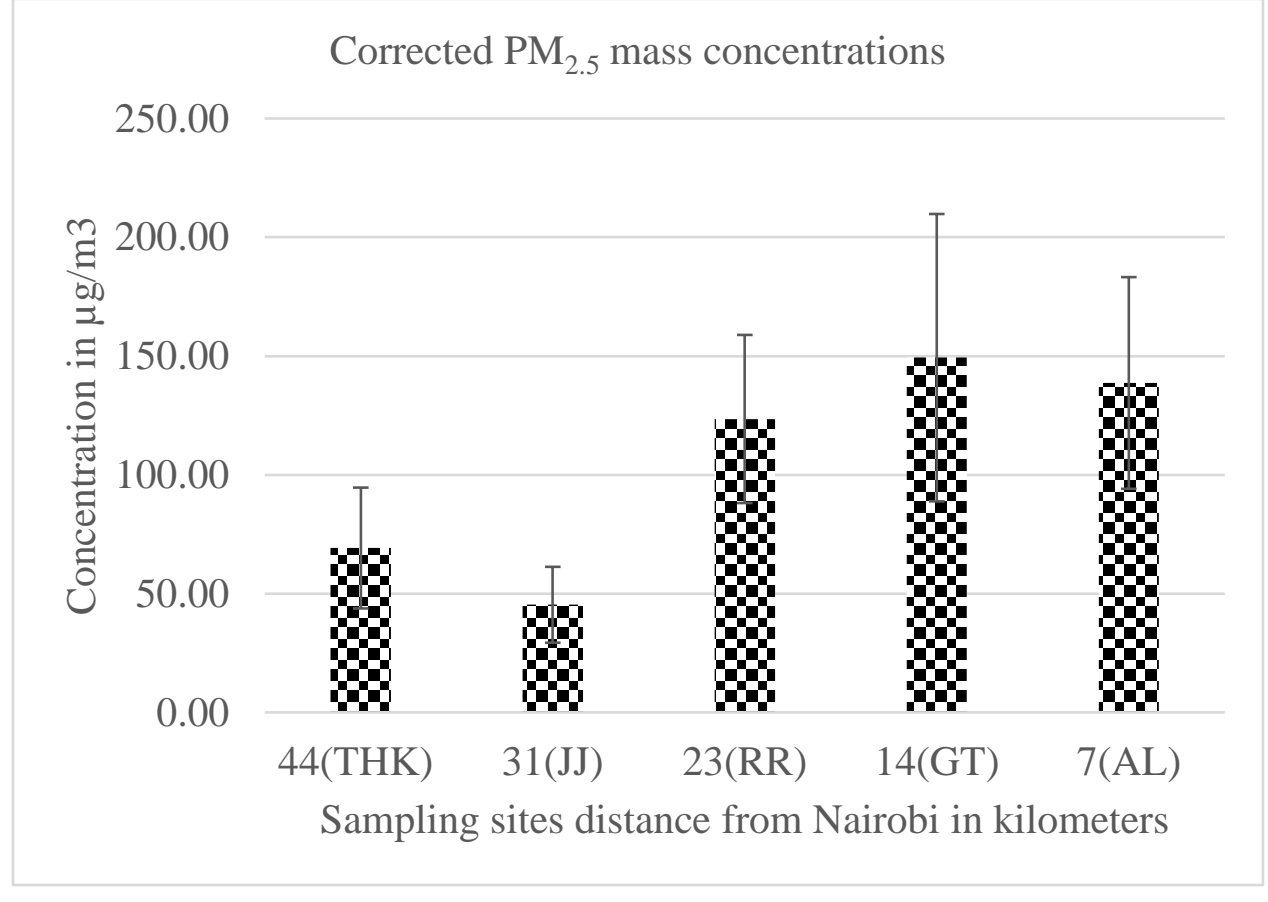


Figure 3: Mean $\mathrm{PM}_{2.5}$ concentrations at five sites along Thika superhighway. All bar graphs show the average $\mathrm{PM}_{2.5}$ of five sampling days, except JJ where one sampling day has been omitted from the calculation due to a dust storm which caused an 8 -hour average of $2365 \mu \mathrm{g} / \mathrm{m}^{3}$ on that day.

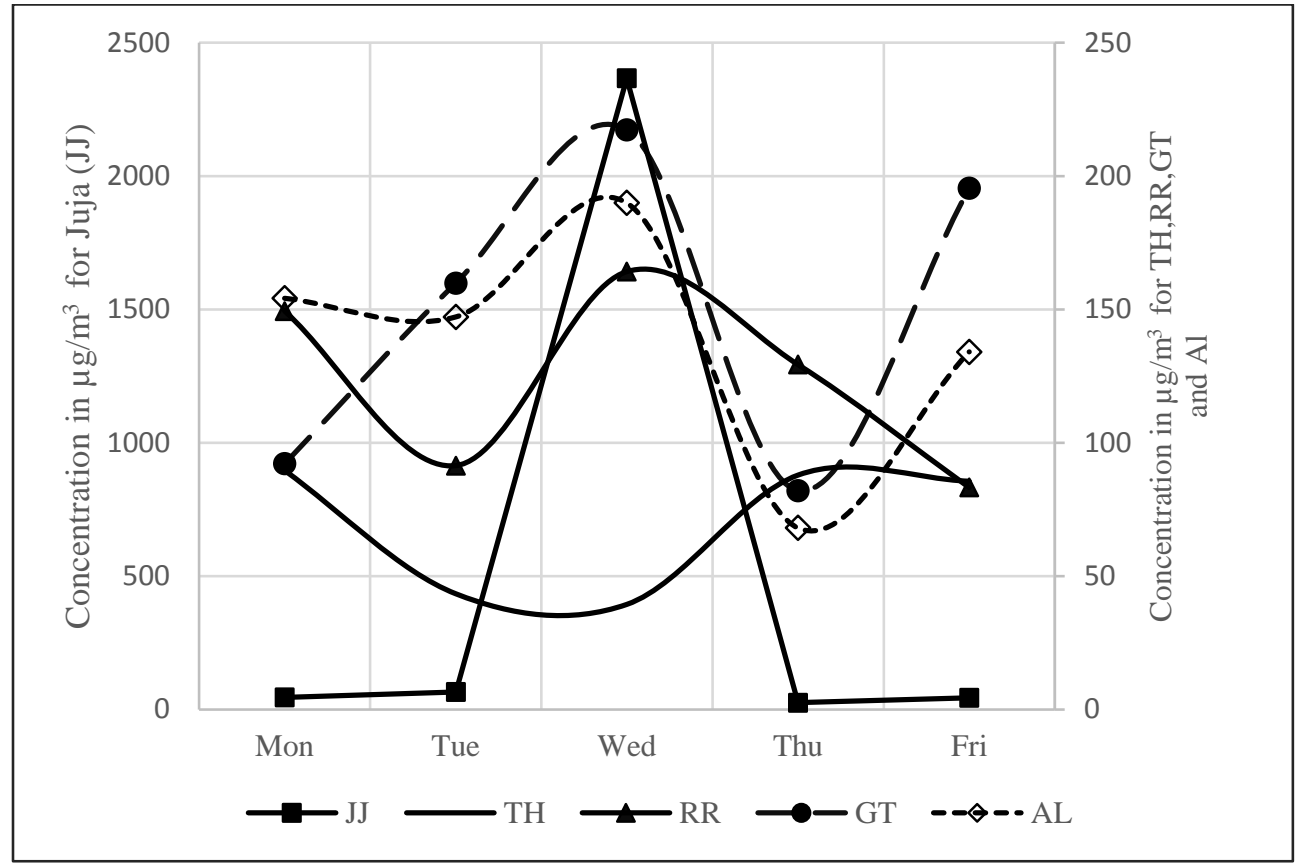

Figure 4: 8-hour $\mathrm{PM}_{2.5}$ concentrations at five sites along Thika superhighway from Monday to Friday.

\section{Health implications}

Exposure to heavy metals in roadside dust occurs by skin contact, inhalation and/or ingestion. The effects of heavy metals in road dust include respiratory system disorders, nervous system interruptions, endocrine system malfunction, immune system suppression and the risk of cancer in later life (Atiemo et al., 2011). The high levels of heavy metals as evident in this study, and particularly $\mathrm{Pb}$ and $\mathrm{Cr}$ which are known to be carcinogenic are of concern in relation to human health, chiefly to children, the vulnerable old and pregnant women living close to and/or using busy roads (Du et al., 2013; Atiemo et al., 2011)

A great number of scientific studies have linked exposure to particle pollution with a variety of problems including premature death in people with heart or lung disease, nonfatal heart attacks, irregular heartbeat, aggravated asthma and decreased lung function (USEPA, 2014). In addition, increased respiratory symptoms such as irritation of the airways, coughing or difficulty in breathing have also been linked to PM exposure (USEPA, 2015). For those people who spend a significant portion of their day on (or adjacent to) the road, e.g. residential homes, street vendors, traffic police, touts and public vehicles drivers, the health consequences of $\mathrm{PM}_{2.5}$ exposures are even greater (Ngo et al, 2015). 


\section{Study limitations}

274

275

276

277

278

279

280

281

282

283

284

285

286

287

288

289

290

291

292

293

294

295

296

297

298

299

300

301

302

303

304

305

The study only covered a short period in the dry season and a more comprehensive study needs to be executed along the highway and in adjacent residential area by the highway. It is important to acknowledge that the roadside dust chemistry results only represent part of the dry season.

Similarly, $\mathrm{PM}_{2.5}$ results reported in this study are just representative of a portion of the dry season. Regardless of these, the results shows that Thika town as well as Thika superhighway is polluted by $\mathrm{PM}_{2.5}$ and poses a health risk to people working in the town and along the highway respectively, who are exposed for long hours and long periods of time (USEPA, 2015; USEPA, 2014; WHO, 2014; WHO, 2016).

The sampling time for $\mathrm{PM}_{2.5}$ was done for only 8 hours a day and not 24 hours at each location and so the results of are not fully comparable to WHO guidelines.

\section{Funding}

This research did not receive any specific grant from funding agencies in the public, commercial, or not-for-profit sectors.

\section{Conclusion}

This study has highlighted the influence of vehicular traffic on road dust chemistry and $\mathrm{PM}_{2.5}$ concentrations along Thika superhighway in Kenya. All the heavy metals analysed $(\mathrm{Cu}, \mathrm{Zn}, \mathrm{Ni}, \mathrm{Cd}, \mathrm{Ni}$ and $\mathrm{Pb})$ in the road dust samples were above the background concentrations at the sampled sites (except Nickel at one sampling site), highlighting the importance of anthropogenic emissions from vehicular traffic. Since roadside dust may be resuspended, these metals especially $\mathrm{Cd}, \mathrm{Pb}$ and $\mathrm{Cr}$ which had higher I-geo and $\mathrm{CF}$ values, pose a significant health risk to people along the highway who may inhale the resuspended polluted dust (Adna et al., 2002). Though not directly comparable, as an indication of air pollution levels, all the sites had $\mathrm{PM}_{2.5}$ 8-hour concentrations above the 24-hour WHO guideline value of $25 \mu \mathrm{g} / \mathrm{m}^{3}$, meaning that some individuals may experience adverse health impacts which include respiratory and cardiovascular morbidity plus mortality from cardiovascular, respiratory diseases and from lung cancer (WHO 2013). Those that use the road frequently, including traffic police, street vendors and local residents along the highway may experience the greatest health impacts due to higher exposures. While this study provides some evidence of the problem, further work needs to include source apportionment studies to quantify the contribution of vehicular traffic to road dust and $\mathrm{PM}_{2.5}$ at the sites in Kenya. Further, while this study has provided initial evidence of $\mathrm{PM}_{2.5}$ concentrations above guideline values, long-term $\mathrm{PM}_{2.5}$ measurements at key sites in Kenya (e.g. important roadways such as Thika superhighway) are needed to more fully understand spatial and temporal variations in particulate air pollution in SSA countries. 
Abah, J., Mashebe, P., Onjefu, S. A. (2014). Survey of the levels of some heavy metals in roadside dusts along Katima Mulilo urban road construction, Namibia. American Journal of Environmental Protection, 3(1), 1927.

Aboh, I. J. K., Henriksson, D., Laursen, J., Lundin, M., Ofosu, F. G., Pind, N., Selin Lindgren, E., and Wahnström, T. (2009). Identification of aerosol particle sources in semi-rural area of Kwabenya, near Accra, Ghana, by EDXRF techniques. X-Ray Spectrom, 38, 348-353

Addo, M.A., Darko, E. O., Gordon, C., Nyarko, B. J. B and Gbadago, J. K. (2012). Metal concentrations in road deposited dust at Ketu-South District, Ghana. International journal of science and technology, 2 (1), 28-39.

Adnan M., Massadeh and Snook R. D. (2002). Determination of $\mathrm{Pb}$ and $\mathrm{Cd}$ in road dusts over the period in which $\mathrm{Pb}$ was removed from petrol in the UK. Journal of Environmental monitoring, 4, 567-572

Ahmed F and Ishiga H. (2006). Trace metal concentration in street dusts of Dhaka City, Bangladesh. Atmospheric Environment. 40, 3835-3844.

Al-Khashman, O. A. (2004). Heavy metal distribution in dust, street dust and soils from the work place in Karak Industrial Estate, Jordan. Atmospheric Environment, 38, 6803-6812.

Amato, F., Pandolfi, M., Escrig, A., Querol, X., Alastuey, A.,Pey, J., Perez, N and Hopke, P. K (2009). Quantifying road dust resuspension in urban environment by Multilinear Engine: A comparison with PMF2. Atmospheric Environment 43, 2770-2780

Atiemo, M. S., Ofosu, G. F., Tutu, A O., Palm, N. D. M. L. and Blankson, S. A. (2011). Contamination assessment of heavy metals in road dust from selected roads in Accra, Ghana. Research Journal of Environmental and Earth Sciences, 3(5), 473-480.

Awadh, S. M. (2013). Assessment of the potential pollution of cadmium, nickel and lead in the road road-side dust in the Karkh district of Baghdad City and along the highway between Ramadi and Rutba , West of Iraq. Merit Research Journal of Environmental Science and Toxicology, 1(7), 126-135.

Boarnet, M. G and Chalermpong, S. (2001). New highways, house prices, and urban development: A case study of toll roads in Orange County, CA. Housing Policy Debate, 12(3), 575-605.

Boman, J., Lindén, J., Thorsson, S., Holmer, B., and Eliasson, I. (2009). A tentative study of urban and suburban fine particles $\left(\mathrm{PM}_{2.5}\right)$ collected in Ouagadougou, Burkina Faso. X-Ray Spectrom, 38, 354-362

Boman, J., Shaltout, A. A., Abozied, A. a. M., and Hassan, S. K. (2013). On the elemental composition of PM2.5 in central Cairo, Egypt. X-Ray Spectrom, 42, 276-283

CAIP. (2000). Motorcycle emissions. Accessed $7^{\text {th }}$ March 2018 from http://pdf.usaid.gov/pdf_docs/Pnacy042.pdf

Chi, G., Vos, P. R and Deller, S. C. (2006). Rethinking highway effects on population change. Public Works Management \& Policy, 11(1), 18-32. DOI: 10.1177/1087724X062923

Cohen, A. J., Brauer, M., Burnett, R., Anderson, H. R., Frostad, J., Estep, K., Balakrishnan, K., Brunekreef, B., Dandona, L., Dandona, R., Feigin, V., Freedman, G., Hubbell, B., Kan, A. H., Knibbs, L., Liu, Y., Martin, R., Morawska, L., Pope III, C. A., Shin, H., Straif, K., Shaddick, G., Thomas, M., Dingenen, 
R., Donkelaar, A., Vos, T., Murray, C. J and Forouzanfa, M. H. (2017). Estimates and 25-year trends of the global burden of disease attributable to ambient air pollution: an analysis of data from the Global Burden of Diseases Study 2015. Lancet; 389, 1907-18.

Du, Y., Gao, B., Zhou, H., Ju, X., Hao, H and Yin, S (2013). Health risk assessment of heavy metals in road dusts in urban parks of Beijing, China. Procedia Environmental Sciences, 18, 299 - 309.

Fengler, W (2010). The World Bank: Demographic Transition and growth in Kenya. Accessed $4^{\text {th }}$ June 2017 from http://www.worldbank.org/

Gaita, S. M., Boman, J., Gatari, M. J., Pettersson, J. B. C. and Janhäll, S. (2014). Source apportionment and seasonal variation of $\mathrm{PM}_{2.5}$ in a Sub-Sahara African city: Nairobi, Kenya. Atmospheric Chemistry and Physics Discussions, 14, 9565-9601.

Gicaci, J. (2015). Annual Development Plan 2016/17. Accessed $3^{\text {rd }}$ March 2108 from http://www.kiambu.go.ke/images/docs/public-notices-and-announcements/COUNTY-ANNUALDEVELOPMENT-PLAN-2016-2017.pdf

Kabui, S. K (2015). Performance analysis of the Nairobi-Thika highway. (A2). Accessed $12^{\text {th }}$ May 2017 from http://civil.uonbi.ac.ke/sites/default/files/cae/engineering/civil/KABUI\%20SIMON\%20KIRAGU.pdf

Kenduiwo, J. K. (2014). Vehicle inventory report. Accessed 27 $7^{\text {th }}$ February 2018 from http://erc.go.ke/images/fsf/GFEI/Vehicle\%20Inventory\%20Report\%204-4-14\%20revised1.pdf

Kenya National Bureau of Statistics. (2013). Statistical Abstract. Accessed $3^{\text {rd }}$ March 2018 from https://www.knbs.or.ke/download/statistical-abstract2013/?wpdmdl=4317\&ind $=$ jFjZdcpMZtX651 whOKW1NfzjtBEmJQjNsW9Ba5hrn5KOYqo8TzYP2pBZon3PK8

Kenya Bureau of Standards. (2014). Motor vehicle inspection overview. Accessed November $1^{\text {st }} 2016$ from http://www.kebs.org/index.php?opt=qai\&view=motor-vehicle-inspection.

Kinney, P. L., Gichuru, M. G., Volavka-Close, V., Ngo, A., Peter K. Ndiba., Law, A., Gachanja, A., Gaita, S. M., Chillrud, S. N. and Sclar, E. (2011). Traffic Impacts on PM $_{2.5}$ Air Quality in Nairobi, Kenya. Environmental Science and Policy, 14(4), 358-366.

Lindén, J., Boman, J., Holmer, B., Thorsson, S., and Eliasson, I. (2012). Intra-urban air pollution in a rapidly growing Sahelian city. Environ. Int, 40, 51-62

Nabulo, G., Oryem, O. H. and Diamond, M. (2006). Assessment of lead, cadmium and zinc contamination of roadside soils, surface films and vegetables in Kampala city, Uganda. Environ. Res. 101: 42-52.

Nairobi County Integrated Development Plan (NCIDP). (2014). Accessed $3^{\text {rd }}$ March 2018 from https://roggkenya.org/wp-content/uploads/docs/CIDPs/Nairobi-County-Integrated-DevelopmentPlan_CIDP 2013-2017.pdf

Ngo, N. S., Gatari, M., Yan, B., Chillrud, S. N., Bouhamam, K., and Kinney, P. L. (2015). Occupational exposure to roadway emissions and inside informal settlements in sub-Saharan Africa: a pilot study in Nairobi, Kenya. Atmospheric Environment, 111, 179-184. 
Ordóñez A., Loredo J., De Miguel E and Charlesworth S. (2003). Distribution of heavy metals in street dust and soils of an industrial city in Northern Spain. Archives of Environmental Contamination and Toxicology. 44:160-170.

Raj, S. P. and Ram, P. A. (2013). Determination and contamination assessment of $\mathrm{Pb}, \mathrm{Cd}$, and $\mathrm{Hg}$ in roadside dust along Kathmandu-Bhaktapur road section of Arniko. Research Journal of Chemical Science, 3(9), 18 25 .

Robertson, D. J., Taylor, K. G and Hoon, S. R. (2003). Geochemical and mineral magnetic characterization of urban sediment particulates, Manchester, UK. Applied Geochemistry, 18, 269-282

Robinson, L.A. and Hammitt, J.K. (2009). The value of reducing air pollution risks in sub-saharan Africa. Accessed $4^{\text {th }}$ August 2017 from http://www.regulatory-analysis.com/robinson-hammitt-air-pollutionafrica.pdf

Shinggu, D. Y., Ogugbuaja, V. O., Toma, I. and Barminas, J. T. (2010). Determination of heavy metal pollutants in street dust of Yola , Adamawa State , Nigeria. African Journal of Pure and Applied Chemistry, 4(1), 1721.

Taylor, S.R., 1964. Abundances of chemical elements in the continental crust: a new table. Geochim. Cosmochim. Acta 28 (8), 1273-1285.

UNEP (2006). Kenya: Integrated Assessment of the Energy Policy with Focus on the Transport and Household Energy Sectors. United Nations Environmental Program, Nairobi, Kenya.

UNEP (2016). Geo-6 regional assessment for Africa. Accessed $4^{\text {th }}$ August 2017 from http://www.uneplive.org/media/docs/assessments/GEO_6_regional_assessment_for_africa_print_finallow_ res.pdf

USEPA (1996). SW 846 Method 3050B, (December), 1-12. Accessed $9^{\text {th }}$ December 2015 from http://www.epa.gov/osw/hazard/testmethods/sw846/pdfs/3050b.pdf

USEPA (2014). Air quality index. A guide to air quality and your health. Accessed $3^{\text {rd }}$ January 2017 from http://www3.epa.gov

USEPA (2015). Health. Accessed $17^{\text {th }}$ February 2015 from http://www3.epa.gov/pm/health.html

Van Vliet, E. D. S. and Kinney, P. L. (2007). Impacts of roadway emissions on urban particulate matter concentrations in sub-Saharan Africa: new evidence from Nairobi, Kenya. Environmental Research Letters, 2,045028 .

Victoria, A., Cobina, S. J., Dampare, S. B and Duwiejuah, A. B. (2014). Heavy metal concentration in roadside dust in the Bolgatanga municipality, Ghana. Journal of Environment Pollution and Human Health, 2,(4), 74-80.

WHO (2013). Health effects of particulate matter. Policy implications for countries in eastern Europe, Caucasus and central Asia. Accessed 11 $1^{\text {th }}$ September 2017 from http://www.euro.who.int/_data/assets/pdf_file/0006/189051/Health-effects-of-particulate-matter-finalEng.pdf?ua=1 
415 WHO (2014). 7 million premature deaths annually linked to air pollution. Accessed $20^{\text {th }}$ November 2017 from http://www.who.int/mediacentre/news/releases/2014/air-pollution/en/

417 WHO (2016). World health statistics 2016: Monitoring health for the SDGs, sustainable development goals. Accessed 6 $6^{\text {th }}$ May 2017 from https://www.ncbi.nlm.nih.gov/pmc/articles/PMC4314252/pdf/ehp.1408646.pdf

Xia, X., Chen, X.,Liu, R., Liu, H. (2011). Heavy metals in urban soils with various types of land use in Beijing.

422 Yu, K. N., Yeung, Z. L and Kwok, R. C. W (2003). Determination of Multi-element profiles of soils using Energy Dispersive X-Ray Fluorescence (EDXRF). Appl Radiat Isot. 58, 339-346.

424 Zachariadis, T., Ntziachristos, $L$ and Samaras, Z. (2001). The effect of age and technological change on motor vehicle emissions. Transportation Research Part D: Transport and Environment, 6, 221-227. 